\title{
多孔型流路を有する固体高分子形燃料電池の性能特性と内部現象解析*
}

\author{
田部 豊*1, 那須 拓哉 ${ }^{* 2}$, 森岡 怜史 ${ }^{* 3}$, 近久 武美 ${ }^{* 4}$
}

\section{Analysis of Performance Characteristics and Internal Phenomena of PEFC with Porous Flow Field}

\author{
Yutaka TABE*1, Takuya NASU, Satoshi MORIOKA and Takemi CHIKAHISA \\ ${ }^{* 1}$ Hokkaido University, Graduate School of Engineering, Division of Energy and Environmental Systems \\ N13 W8, Kita-ku, Sapporo, 060-8628 Japan
}

\begin{abstract}
A polymer electrolyte membrane fuel cell (PEFC) with a porous-flow-field separator has been proposed as an alternative to cells with gas flow channels. In this study, basic characteristics of a PEFC with porous flow field were identified using a cell allowing local current density measurement and direct observation of the condensed water at the surface of porous material. It was shown that a stable operation can be maintained under conditions at high current density and low stoichiometric ratio of cathode air, but an operation with low relative humidity of reaction gases is difficult with the porous type separator. To clarify the detailed causes of these characteristics, the internal phenomena were investigated using a cell specially made for the cross-sectional observation of the separator or the temperature distribution measurement. The direct observations of the condensed water at the cross-section of porous flow field showed that the porous type cell is superior in drainage performance of the condensed water from the surface of gas diffusion layer (GDL), and the hydrophilic property of the porous material is important for better cell performance under high current density conditions. The measurements of temperature distribution on the anode GDL surface indicated that the increase in temperature near the reaction area tends to be larger in the porous type cell than in channel type due to the lower thermal conductivity of the porous media, and this resulted in the unstable operation with low relative humidity conditions.
\end{abstract}

Key Words : Polymer Electrolyte Fuel Cell, Porous Media, Separator, Water Management, Hydrogen Energy

\section{1. 緒言}

固体高分子形燃料電池（PEFC: Polymer Electrolyte Fuel Cell）は，低環境負荷型の高効率エネルギー変換機器お よび次世代の水素有効利用機器として, 自動車用動力源や定置型分散電源, 携帯用電源などとしての利用が期待 されている．PEFC の実用化において高出力運転での性能向上が課題の一つであるが，反応による生成水が過剩 な際に凝縮水が反応ガスの供給阻害を引き起こすフラッディングや, 逆に固体高分子膜が低湿潤状態となった際 にプロトン伝導性が低下寸るドライアウトなど, 電池内では性能低下に繋がる種々の現象が生じる. したがって, 電池内の反応ガス供給と生成水排出, および温度管理が極めて重要であり, 反応ガスを供給し生成水を排出する 機能を有するセパレータ (バイポーラプレート) の適切な設計が必要となる.

PEFC の反応面にガスを供給する方法として，ガス流路を有するセパレータを用いる方式が広く採用されてお

\footnotetext{
* 原稿受付 2011 年 11 月 24 日

*1 正員, 北海道大学大学院工学研究院（广060-8628 北海道札幌市北区北 13 条西 8 丁目）

*2 学生員, 北海道大学大学院工学院

*3 北海道大学大学院工学研究科

${ }^{*} 4$ 正員, フェロー, 北海道大学大学院工学研究院

E-mail: tabe@eng.hokudai.ac.jp
} 
り，様々な流路形状を有する電池の基本特性が調べられている(1)(2)(3)．また，電流密度分布測定による発電の均一 性と性能特性との関係 ${ }^{(4)(5)}$ や, 可視化燃料電池を用いた直接観察による流路内の凝縮水排出挙動 ${ }^{(6)(7)}$ についても, 多くの研究が報告されている.さらに, 電流密度分布と流路内の凝縮水分布の同時計測や可視化構造に赤外線透 過空を用いたサーモグラフィによる温度分布計測も行われており ${ }^{(3)(8)}$, 著者らはサーペンタインおよびストレート 流路型電池に対し，それぞれの流路形状特有の凝縮水および反応ガス流動と発電特性との関係を明らかにしてい る ${ }^{(9)}$. 一方, 発電の不均一化につながる流路・リブ構造を避けるために, 多孔型流路を用いたセパレータが提案 されており，ある条件において性能向上が見込まれることが示されている(10). また，多孔型流路内の凝縮水挙動 に対する二相流シミュレーションより，多孔体型セパレータの排水特性が解析されている(11). しかし，種々の条 件における多孔型流路を有する電池の発電特性や, 電池内部の凝縮水および反応ガス流動などの内部現象が電池 性能に及ぼす影響は十分に解明されていない.

そこで本研究では，多孔型流路を有する燃料電池の基本特性について，サーペンタインおよびストレート流路 型電池と比較することにより, 実験的な解析を行った. さらに, 多孔体型電池に対し, 高加湿, 高電流密度条件 で良好な性能を示した原因を多孔体断面での凝縮水直接観察により調べるとともに，低加湿条件で性能悪化した 要因を温度分布測定により検討し，基本特性に対応する電池内部現象の解明を試みた。

\section{2. 実験装置および方法}

実験は，電流密度分布測定用および内部可視化用のセル A と，多孔体断面の凝縮水挙動の可視化または温度分 布測定用のセル B の 2 種類の PEFC 単セルを用いて行った．それぞれ反応面積は，10×10 $\mathrm{cm}^{2}$ および $5 \times 5 \mathrm{~cm}^{2}$ であ り, セル構造の概略図を図 1 に示寸. 図 1 中央がセル A で, 膜電極接合体 (MEA: Membrane Electrode Assembly) をガス拡散層 (GDL: Gas Diffusion Layer)，セパレータ・集電板, 端板で挟む構造となっている. GDLには, MEA 側にマイクロポーラスレイヤー（MPL）が塗布された厚さ $0.3 \mathrm{~mm}$ のカーボンペーパを用い，カソード側セパレー タには, 多孔体型, サーペンタイン流路型, またはストレート流路型を用いた (図 1 は多孔体型を使用した場合). 多孔型セパレータは，平均空隙率約 97\%の図 1 右上のような構造の多孔体を金メッキを施した集電用の銅板には め込んだ構造であり, 多孔体の材質は $\mathrm{Ni}$, 厚さは $1.4 \mathrm{~mm}$ である. カソード端板にはガラス空が設置されており, 多孔体表面の凝縮水挙動を観察することが可能である. また，サーペンタイン，ストレート流路は，幅，ピッチ ともに $2.0 \mathrm{~mm}$ であり，金メッキを施した厚さ $0.5 \mathrm{~mm}$ の銅板のセパレータにおいて，流路部が貫通構造となって いる. これより, 流路高さが $0.5 \mathrm{~mm}$ となり, 流路内の凝縮水挙動が空を通して観察可能である ${ }^{(9)}$. 一方, ストレ

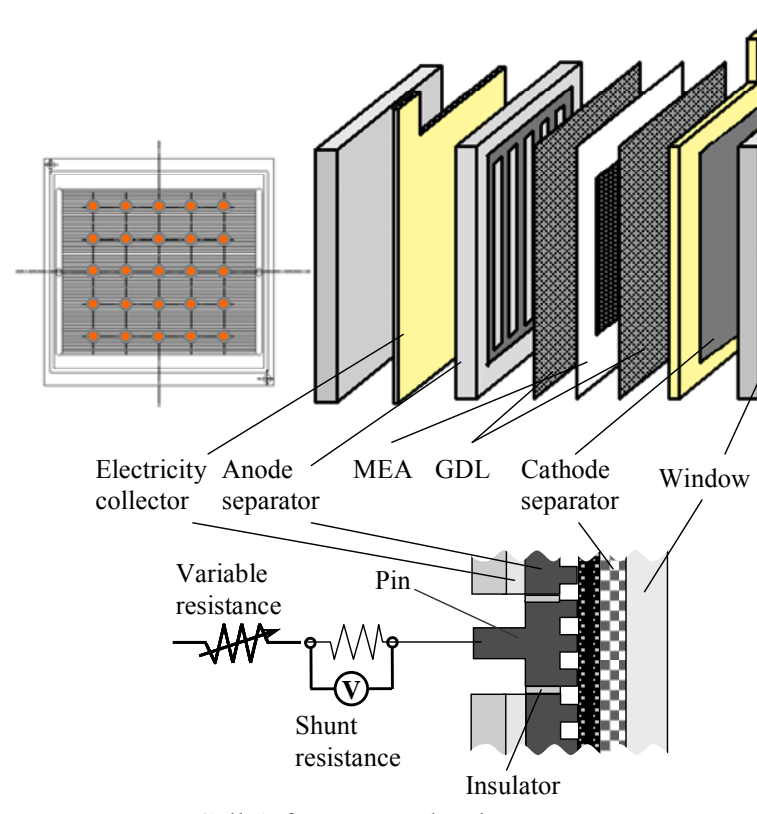

Cell A for current density measurement and direct observation

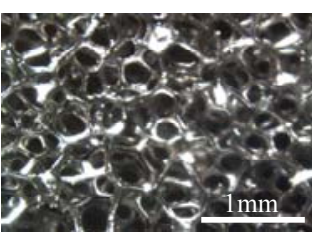

Porous material

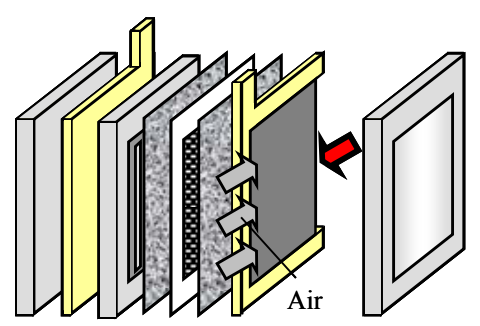

Cell B for cross-section observation

Fig. 1 Experimental apparatus for visual observations, current density and temperature measurements 
ート流路型のアノード側セパレータには, 図 1 左に示した通り電流密度分布測定用のピンが縦横等間隔に 25 本配 置されている. 直径 $5.5 \mathrm{~mm}$ のピンは周囲と絶縁され $0.1 \Omega$ のシャント抵抗に繋がれており (図 1 左下は断面図), これらのシャント抵抗の電圧降下から電流密度分布を計測した。 ここで，ピンを挿入したことによる接触抵抗の ばらつき影響については，後部に接続された可変抵抗を調節して補正するとともに運転初期の一様な低電流密度 運転時の分布を用いたデータ整理を行うことにより低減し，より正確な電流密度分布を得ることを可能としてい る(詳細は参考文献(9)).

図 1 右下に示したセル B は, 多孔体セパレータ断面の凝縮水挙動を可視化するために作成したものであり, 電 流密度分布測定用のセル A とほぼ同様の構造をしている.ただし，カソード側集電用銅板の下流側 1 辺が開放さ れており, 図の赤矢印の多孔体断面から内部の凝縮水挙動が観察可能となっている. なお，セル A では下流部端 の端板側全体がマニホールドに開放されている構造であり, 両者の構造の違いが発電性能に及ぼす影響の差異は 小さいと考えられる．観察には実体顕微鏡（LEICA, Z16APO）を用い，アノード側セパレータは電流密度測定用 の機能は有していない. また, 温度分布測定においては, セル B のアノードセパレータをセル A のカソード可視 化構造と同様とし（このときカソード側は観察用開放部の無い銅板・集電板，空材扱入部の無い端板を使用），赤 外線を透過するサファイアガラスを空材に用いることにより，アノード側から温度分布をサーマルカメラ (NEC, TH5104R）で測定した. ここで，アノード側から温度分布測定を行ったのは，異なるセパレータタイプにおいて も比較的反応部に近い同一条件の側から温度比較をできることに加えて, アノード側では凝縮水が流路側の GDL 表面まで排出されづらく，凝縮水による放射率の変化が測定結果に及ぼす影響を小さくできるためである.

セルは，恒温槽内に図 1 に示すように垂直（紙面下が重力方向）に設置した．セル A は，恒温槽温度とアノー ド側集電板と端板の間に挿入した冷却水プレート（図 1 では非表示）を用いて実験中の温度を一定に保ち，セル $\mathrm{B}$ は，恒温槽温度のみで運転開始時の温度を制御した。制御用の温度は，セル A はカソードセパレータ内の上流 付近，セル B はカソードセパレータの集電板側表面に設置した熱電対により測定した. アノードガスとして純水 素, カソードガスとして模擬空気（酸素 $21 \%$, 窒素 $79 \%$ ）または純酸素をコフローで供給し, バブラ温度により 供給ガスの相対湿度を制御した。 また，セル抵抗は $1 \mathrm{kHz}$ の交流インピーダンスメータにより，カソードガスの 圧力損失はガス供給入口に設置した微差圧計により測定し，実験中のセル電圧，セル温度，供給ガス温度などの データとともに PCに取り込み記録した。

\section{3. 実験結果および考察}

\section{$3 \cdot 1$ 発電特性と気液流動および電流密度分布}

セル A において, カソード側に多孔体型またはサーペンタイン流路型セパレータを用いた場合の分極特性を図 2 に示す．ここで，各分極特性の測定は，電流密度を徐々に上げていき，それぞれの測定電流密度で 3 分程度の 運転後に得られた值を用いている. カソードガスとして空気を供給し, 流量は電流密度に応じてストイキ比入（供 給流量の発電に最低限必要な理論流量に対する比)で 1.4 または 2.0 に変化させた.アノードガスの純水素流量は, $\lambda=2.5$ である. カソード側を後にセル A の長時間運転の条件として用いる $\lambda=2.5$ よりも小さい值としたのは, 短

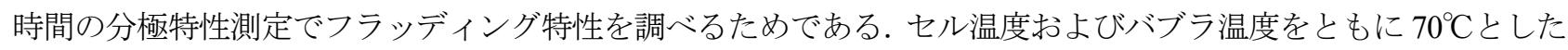
100\%加湿ガスを供給した条件である. 低流量である $\lambda=1.4$ の場合は, サーペンタイン流路型では電圧が降下して 測定不能であったのに対し, 多孔体型では $0.7 \mathrm{~A} / \mathrm{cm}^{2}$ までの運転が可能であった. 高流量の $\lambda=2.0$ では, $0.8 \mathrm{~A} / \mathrm{cm}^{2}$ まではサーペンタイン型のセル電圧は多孔体型に比べ高く保たれている.ここで, 電流密度 $0.4 \mathrm{~A} / \mathrm{cm}^{2}$ でのセル抵 抗は，多孔体型が約 $0.6 \Omega \mathrm{cm}^{2}$ に対し，サーペンタイン流路型が約 $0.3 \Omega \mathrm{cm}^{2}$ であった。これは主に多孔体型セパレ 一タの構造の影響, すなわち多孔体とセパレータ枠部, GDL との接触抵抗が大きくなりやすいことが原因と推察 される.これらのセル抵抗から計算される抵抗過電圧は, 電流密度 $0.4 \mathrm{~A} / \mathrm{cm}^{2}$ において多孔体型で $0.2 \mathrm{~V}$, サーペン タイン流路型で $0.1 \mathrm{~V}$ であり, 中電流密度域での電圧差は, 主に電気抵抗の過電圧によるものと考えられる. また, $0.8 \mathrm{~A} / \mathrm{cm}^{2}$ 以上の高電流密度域では, サーペンタイン流路型の電圧低下が大きくなり, これは生成水が酸素供給を 妨げるフラッディングによる濃度過電圧の影響のためと推定される。一方，多孔体型の電圧は濃度過電圧の影響 をほとんど受けておらず, $0.9 \mathrm{~A} / \mathrm{cm}^{2}$ では多孔体型とサーペンタイン流路型のセル電圧が逆転している. 以上より， 多孔体型セパレータを用いた電池は, サーペンタイン流路型を用いた場合よりも耐フラッディング性に優れ, 低 


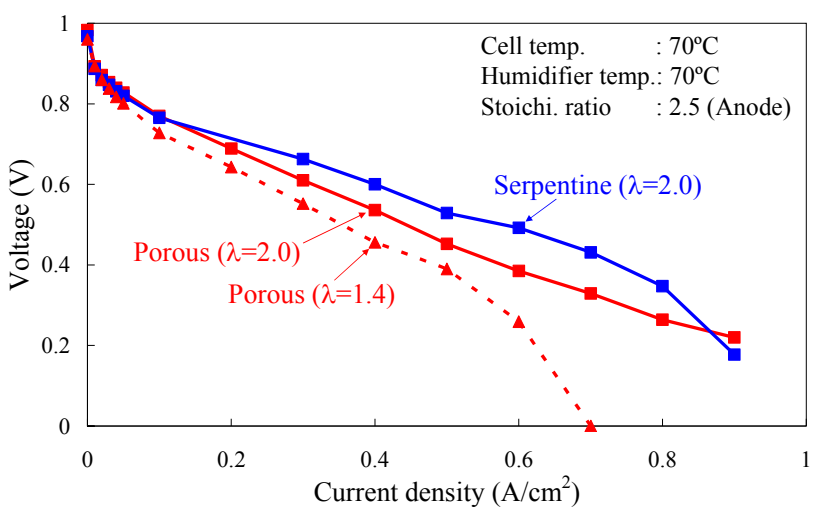

Fig. 2 Comparison of polarization curves between the cells with porous flow field and serpentine channels

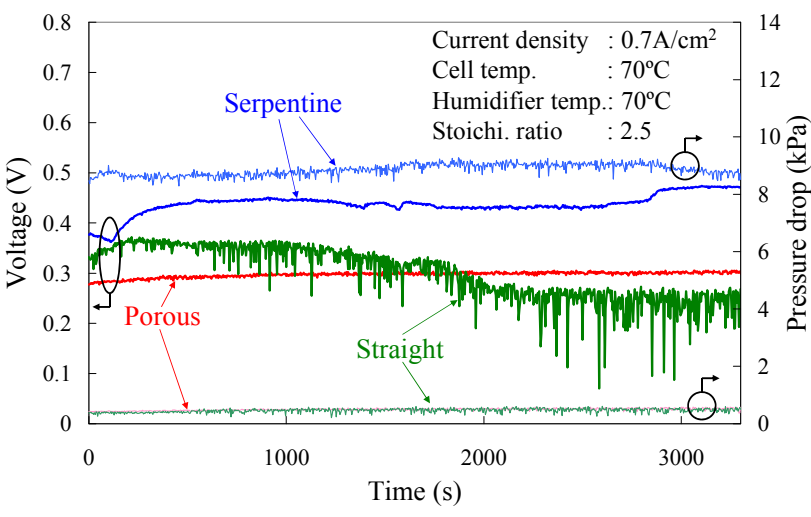

Fig. 3 Cell voltage and pressure drops in the cathode flow for three different flow field types, porous, serpentine and straight channels

空気流量および高電流密度運転に有利であると言える．また，多孔体と他のセル部材との接触抵抗を小さくし抵 抗過電圧の影響を減少させることが，多孔体型セパレータを用いた電池の課題である.

図 3 は, 電流密度 $0.7 \mathrm{~A} / \mathrm{cm}^{2}$ でのセル電圧とカソードガス圧力損失の時間変化を, 多孔体型, サーペンタイン流 路型，ストレート流路型セパレータで比較したものである. セル温度は $70^{\circ} \mathrm{C}$ ，カソード空気，アノード純水素は ともに $\lambda=2.5$, 相対湿度 $100 \%$ でる. サーペンタイン流路型のセル電圧は，運転開始 500 秒に定常状態となった 以後は高い值で保たれており，多孔体型についても抵抗過電圧の影響で值こそ低いものの長時間安定的な運転が 可能となっている，一方，ストレート流路型のセル電圧は大きな振動を伴い徐々に低下しており，凝縮水の排出 性が悪い特性(9)が表れている. カソードガスの圧力損失については, 流路長の長いサーペンタイン流路型で極端 に大きくなっているのに対して，多孔体型ではストレート流路型とほぼ同等のレベルに抑えられている.すなわ ち, 多孔体型セパレータでは, 低い圧力損失でサーペンタイン流路型と同等の凝縮水排出および電圧変動の小さ な運転が可能である.

図 4 は，カソード内の凝縮水可視化観察と電流密度分布の同時計測による結果の一例であり，多孔体型とサー ペンタイン流路型を比較している. 平均電流密度は $0.7 \mathrm{~A} / \mathrm{cm}^{2}$, セル温度は $70^{\circ} \mathrm{C}$, カソード空気, アノード純水素 はともに $\lambda=2.0$, 相対湿度 $100 \%$ あり, 十分に時間が経過して定常状態になったときの結果である. サーペンタ イン流路型は, 右下部のガス下流部に僅かに凝縮水が観察され（破線で囲った部分）, このときガス下流部で電流 密度が低下している．これは，サーペンタイン流路型は，流路内の凝縮水に加えリブ下 GDL 内をバイパスする ショートカット流による供給ガスの不均一性も影響し, 電流密度の分布が大きくなりやすい特性があるためであ る ${ }^{(9)}$. 一方，多孔体型では凝縮水は多孔体表面にはほとんど現れず，サーペンタイン流路型に比べて一様な発電 状態となっている．下流部下側に僅かに凝縮水が見られるのは重力の影響，下流部上側に僅かな電流密度の低下 が見られるのは初期の接触抵抗調整での誤差などが理由として挙げられる.これより多孔体型では, 流路とリブ による不均一性もなく, また多孔体内部に分布していると推察される凝縮水も発電に悪影響を及ぼさないため, 電流密度分布が比較的一様に保たれ, 低流量・高電流密度運転が可能になるものと考えられる. 多孔体型では, 供給ガスが流れる断面積が大きく平均流速が遅くなることからプラッギングが生じやすくなることも懸念された が，長時間の安定運転が可能なことと可視化観察の結果から生成水は多孔体表面まで移動する前に多孔体内で円 滑に排出されていると推察される，なお，流量の小さい純酸素運転では下流部に空気運転より多くの凝縮水が現 れるものの比較的一様な電流密度分布が保たれること, またセルの姿勢が多孔体型電池の発電特性に及ぼす影響 が少ないことも確認している. $3 \cdot 2$ 節では, 生成した凝縮水が多孔体型電池の発電に悪影響を及ぼさない理由に ついて, 多孔体内の凝縮水挙動を観察することにより検討を行う.

図 5 は, バブラ温度 $\mathrm{T}_{\mathrm{b}}$ を $70^{\circ} \mathrm{C}$ から $50^{\circ} \mathrm{C}, 40^{\circ} \mathrm{C}$ と低下させることにより，供給ガスの相対湿度を下げた低加湿 条件でのセル電圧とセル抵抗の時間変化を, 多孔体型とストレート流路型で比較した結果である.ここで, 低加 湿条件では電池性能が電池温度に大きく影響を受けるため，今回の比較ではストレート流路型と同じ温度制御条 件（恒温槽温度および泠却水温度, 流量）で多孔体型の実験も行った。 なお， ストレート流路型は，ガス流速が 遅いために凝縮水が滞留しやすく, 高分子膜が低湿潤状態になりセル抵抗が上昇するドライアウトの影響は受け 


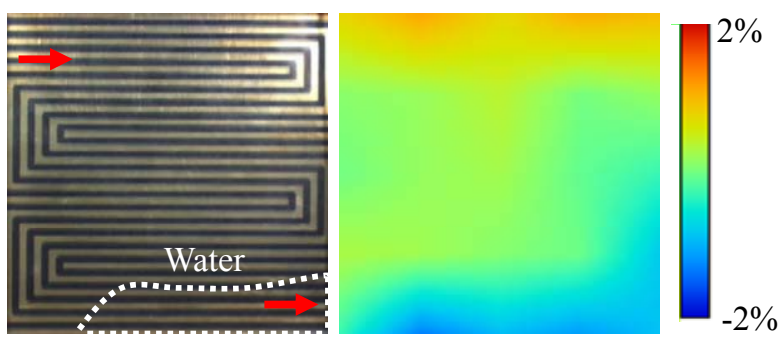

(a) Serpentine channels

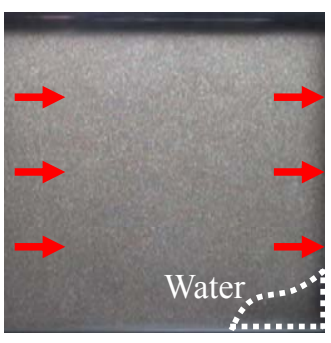

(b) Porous flow field

Fig. 4 Direct view of the cathode sides (left side) and current density distribution (right side) in the cell with serpentine channels and the porous flow field

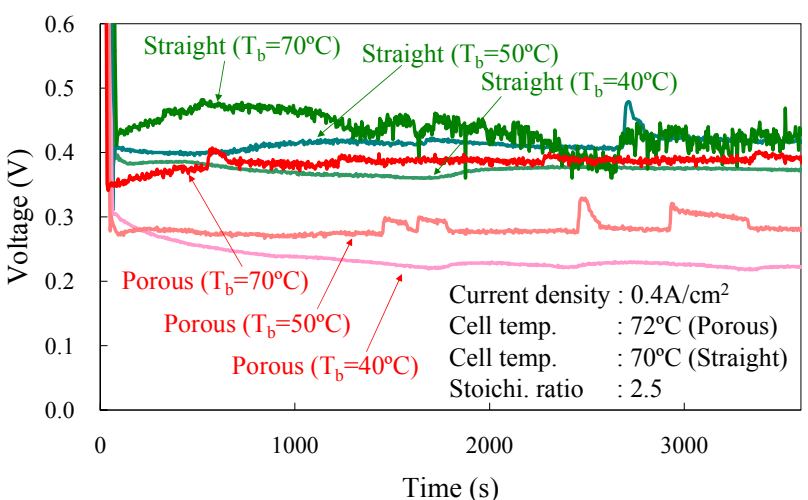

Fig. 5 Effect of relative humidity of supplied gases on cell voltage for the cells with porous flow field and straight channels

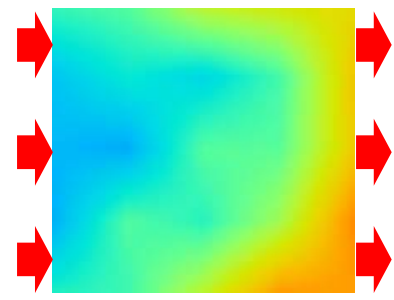

3 minutes after loading

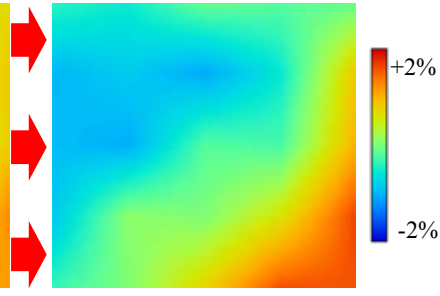

Shutdown
Fig. 6 Change of current density distribution at shutdown of the cell with porous flow field

づらい構造として比較対象とした. 電流密度は $0.4 \mathrm{~A} / \mathrm{cm}^{2}$, セル温度はストレート流路型が $70^{\circ} \mathrm{C}$, 多孔体型が $72^{\circ} \mathrm{C}$, カソード空気，アノード純水素はともに $\lambda=2.5$ である。 ストレート流路型では，フラッディングの影響を受けて 電圧変動が大きいバブラ温度 $\mathrm{T}_{\mathrm{b}}=70^{\circ} \mathrm{C}$ 場合に比べ, $\mathrm{T}_{\mathrm{b}}=50^{\circ} \mathrm{C}$ ではフラッディング影響が小さくなり, さらに低加 湿条件である $\mathrm{T}_{\mathrm{b}}=40^{\circ} \mathrm{C}$ ではセル電圧が僅かに低下している．これは，高分子電解質膜の湿潤状態の低下により， セル抵抗が増加したためと考えらえる。一方, 多孔体型では $\mathrm{T}_{\mathrm{b}}=70^{\circ} \mathrm{C}$ からフラッディングによる電圧変動が小さ いものの, $\mathrm{T}_{\mathrm{b}}=50^{\circ} \mathrm{C}, 40^{\circ} \mathrm{C}$ と低加湿条件になることにより大幅なセル電圧の低下が確認される. これより, 多孔体 型セパレータを用いた電池は，低加湿条件下での運転おいて膜の湿潤状態が悪化しやすく，ドライアウトの影響 を受けや寸いと言える．図６は，冷却水による温度制御をしなかった低加湿運転時に多孔体流路型のセル温度が 上昇し，発電停止までに至った場合の電流密度分布変化を示したものである．運転開始時のセル温度は $45^{\circ} \mathrm{C}$ ，供 給ガスの相対湿度は $\left.33 \% （ \mathrm{~T}_{\mathrm{b}}=25^{\circ} \mathrm{C}\right)$ であり，電流密度 $0.7 \mathrm{~A} / \mathrm{cm}^{2} ，$ カソード側空気とアノード側純水素をともに よりドライアウトの影響を受けや寸い条件である $\lambda=4.0$ で供給した. 左側が発電開始 3 分後, 右側が 7 分後のシ ヤットダウン直前の電流密度分布であり, 空気は左側から流入し右側から排出される構造となっている. 図より, ガス流入口付近における電流密度が低く，排出口付近で高い傾向があり，シャットダウン直前ではその分布が大 きくなっていることがわかる．これは，低加湿空気が流入する入り口側でドライアウトが進行，電流密度が低下 し，その分の負荷電流を確保するために生成水によって加湿される下流側で電流密度の集中が生じたためと考え らえる．また，時間とともにセル温度が上昇，これによりドライアウトの影響による電流密度分布の偏りが顕著 となり，この偏りがセル電圧の低下，さらにはシャットダウンを引き起こすものと推察される，なお，図 6 にお いて右下部の電流密度が高くなる傾向がある理由は，電池周囲の温度境界条件やセル締め付け圧の僅かな不均一 性が引き起こす接触熱抵抗の違いなどが可能性として挙げられる. $3 \cdot 3$ 節では, 多孔体型セパレータを用いた電 池が低加湿時にドライアウトの影響を受けや寸い理由について，電池内の温度分布測定を行うことにより検討を 行う.

\section{$3 \cdot 2$ 多孔体内の凝縮水挙動と耐フラッディング性能}

多孔体内の凝縮水挙動を直接観察することにより，優れた耐フラッディング性能を有する多孔型流路を用いた 電池内の凝縮水排出機構について検討を行った，セル B において，カソード側セパレータを断面観察用とし，多 孔体断面の凝縮水挙動を撮影した結果が図 7 である. 運転開始時のセル温度は $45^{\circ} \mathrm{C}$, 供給ガスの相対湿度は $100 \%$ 


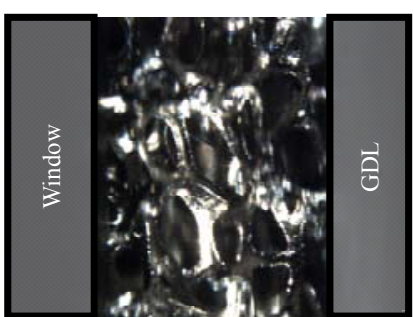

(a) $0 \mathrm{~s}$

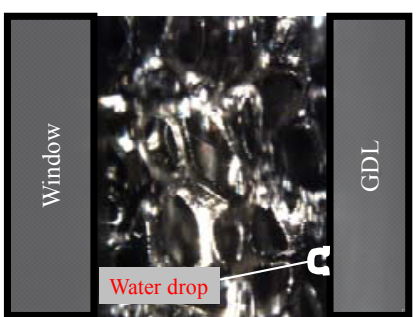

(b) $0.1 \mathrm{~s}$

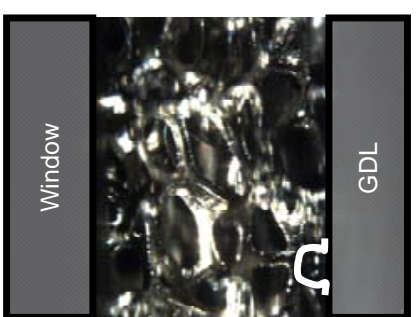

(c) $4.2 \mathrm{~s}$

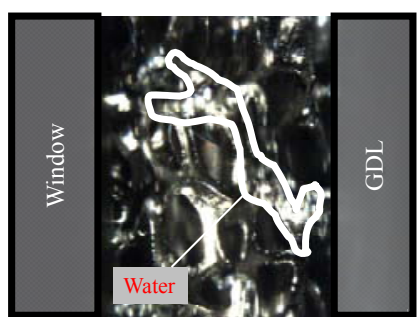

(d) $4.5 \mathrm{~s}$

Fig. 7 Direct view of liquid water transport in the cross-section of the hydrophilic porous separator, times are just after droplet emerging from GDL

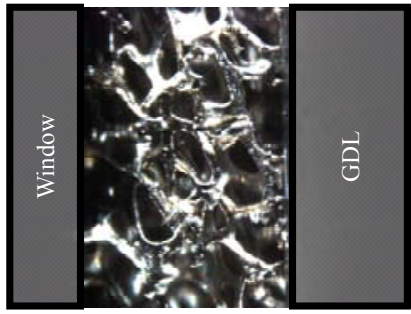

(a) $0 \mathrm{~s}$

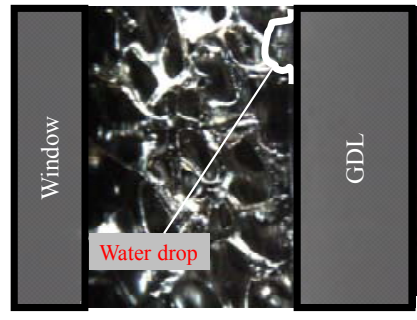

(b) $0.6 \mathrm{~s}$

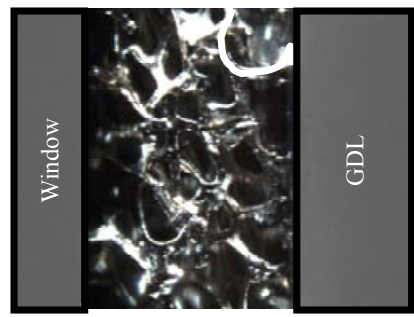

(c) $145.5 \mathrm{~s}$

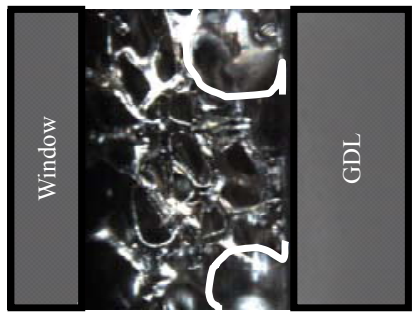

(d) $352.5 \mathrm{~s}$

Fig. 8 Direct view of liquid water transport in the cross-section of the hydrophobic porous separator, times are just after droplet emerging from GDL

(a) Water drop (b)

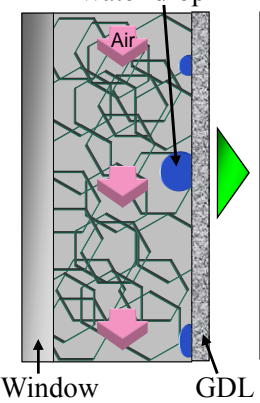

(c)
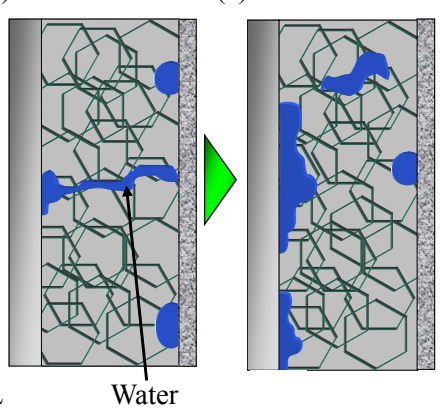

Fig. 9 Schematic view of the transport mechanism of liquid water inside the porous separator

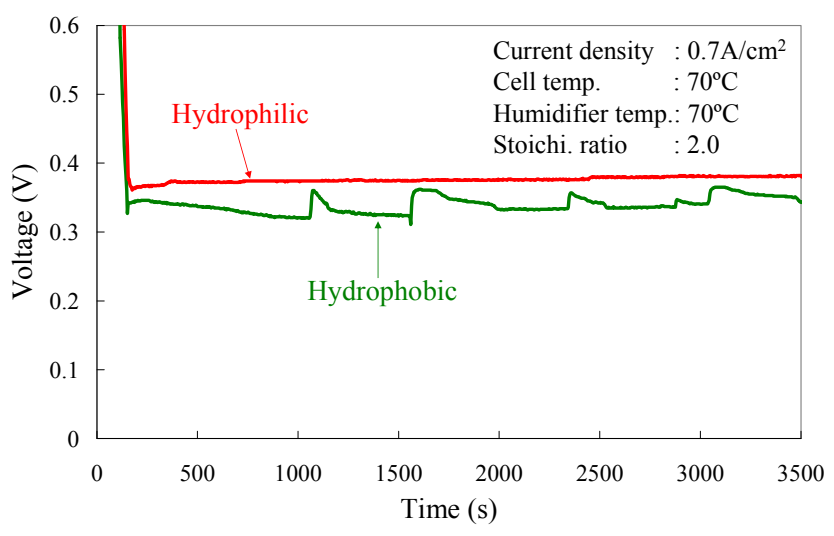

Fig. 10 Comparison of cell voltage between with the hydrophilic and with the hydrophobic porous separators

であり, 電流密度 $0.4 \mathrm{~A} / \mathrm{cm}^{2}$, カソード側空気 $\lambda=2.7$, アノード側純水素 $\lambda=5.4$ で供給した. セル $\mathrm{A}$ の条件に比べ 温度を低くした理由は，可視化や後に示す温度測定の装置の関係でセル温度を高温に保つことが困難であったた めである. また，同条件において多孔体に対して撥水処理を行った場合の断面撮影結果を図 8 に示寸. なお，図 7,8 ともに凝縮水が観察されはじめた時点を 0 秒と示しており, 白線で囲った部分が凝縮水である.

はじめに，通常の撥水処理を施さない多孔体内の凝縮水挙動（図 7）について，模式図 9 を用いて説明する. 運転開始から約 190 秒後に, 写真では右側の GDL 表面の特定の場所から水滴が排出され始める(図 7(b), 図 9(a)). 特定の場所から離散的に水滴が排出されるのは, 撥水性の GDL 内では比較的大きな空孔の中を凝縮水が選択的 に移動するためである ${ }^{(11)}$. 水滴が成長し (図 7(c)), 多孔体の繊維に接触すると直ちに, 凝縮水は繊維に沿って広 がり，GDL 表面から引き上げられる (図 7(d), 図 9(b))。これは，Ni 製の多孔体䋊維が親水性の特性を持ってい るためと考えられる. 多孔体繊維に広がった凝縮水は, 親水性のガラス空表面にも広がり, 反応ガスの流れによ ってセル外部へと排出されながら, 多孔体内を閉塞させることなく定常状態を維持できるものと推察される（図 9(c))。このように, 多孔体型セパレータは, GDL 表面に排出された凝縮水をすぐに多孔体繊維により引き上げる ことから，GDL 表面の凝縮水排出性に優れていると言える.また，多孔体䋊維やガラス空に広がった凝縮水は， 流路型に比べて遅い平均流速を持つカソードガスによっても円滑に電池外へと排出されるものと考えられる. 次 に, 撥水処理を行った多孔体内の凝縮水挙動を示した図 8 について, 図 7 との比較を行う. 親水性の多孔体型セ 
パレータと同様に GDL 表面に水滴が排出され始める(図 8(b)). しかし，水滴は多孔体繊維に接触してもその場に 滞留し続け，大きな滴径へと成長する(図 8(b),(c)). 図 8 では, 凝縮水が多孔体断面から前面側の多孔体外部へと 排出されかかっているため水滴は多孔体の空孔以上の大きさとなっているが(図 $8(\mathrm{c}),(\mathrm{d}))$, 凝縮水が多孔体繊維に 接触しても GDL 表面に滞留し続ける挙動は多孔体内部でも生じていると推察される. このように，撥水性の多 孔体を用いた場合は, 通常の親水性の多孔体が有する凝縮水を GDL 表面から吸い上げ広げる機能が損なわれる 様子が確認できた.

図 10 は，セル A を用い，通常の多孔体を用いた場合と撥水処理を施した多孔体を用いた場合のセル電圧の時

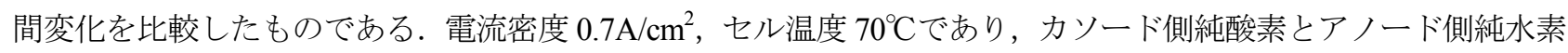
をともに $\lambda=2.0$, 相対湿度 $100 \%$ で供給した. 前述したように通常の多孔体型セパレータではセル電圧が安定に保 たれたまま運転可能であるのに対し，撥水性の多孔体ではセル電圧の振動が確認できる。これは，図 8 のように 凝縮水が GDL 表面に滞留しやすくなり, 滞留する水滴によって GDL 内へのガス拡散性が悪化するためであると 推察される. 以上より, 多孔体型セパレータでは, GDL 表面に排出された凝縮水をすぐに多孔体繊維により GDL と離れた端板側に引き上げることが可能であり, GDL 表面からの優れた凝縮水排出性を有することが確認された. これより, GDL 内部へ効率よく酸素を供給することが可能となり, 凝縮水の影響を受けやすい低流量および高電 流密度運転において優れた発電性能, および電圧変動の少ない安定運転が実現可能になるものと考えられる.ま た，多孔体型セパレータを用いた電池の優れた耐フラッディング特性において，親水性である多孔体の特性が重 要であることが明らかとなった。

\section{$3 \cdot 3$ 電池内温度分布と耐ドライアウト性能}

セル B を用いた場合の高加湿時および低加湿時の運転特性を図 11 に示す。ここで, アノード側を温度測定用 のセパレータとし，カソード側は観察用開放部の無い銅板・集電板，空材挿入部の無い端板を使用した。図 11(a) が，供給ガスの相対湿度を $100 \%$ とした場合の多孔体型とサーペンタイン流路型，図 11(b)が供給ガスの相対湿度 を 33\%とした場合の多孔体型とストレート流路型のセル電圧およびセル抵抗変化を比較した結果である. 運転開

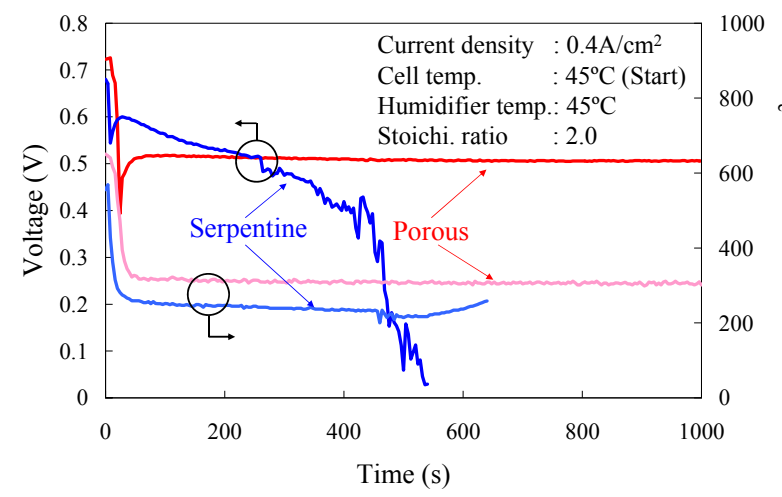

(a) High relative humidity, RH $100 \%$ (Start)

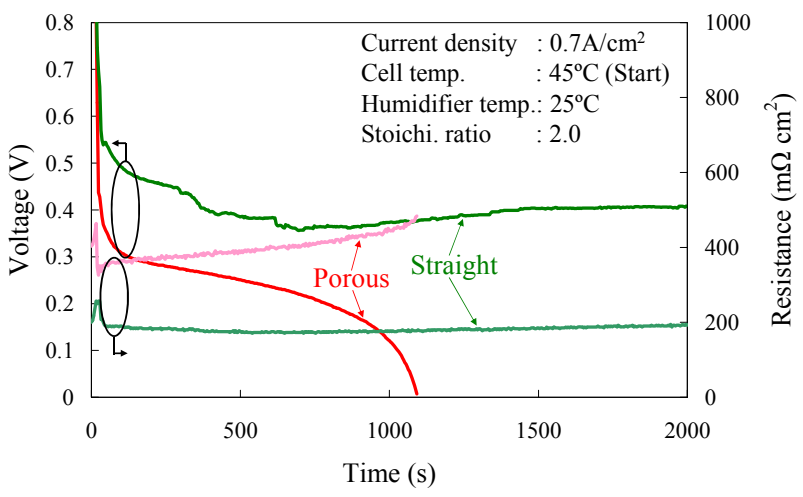

(b) Low relative humidity, RH 33\% (Start)

Fig. 11 Comparison of cell voltage and resistance for different separator types and relative humidity conditions

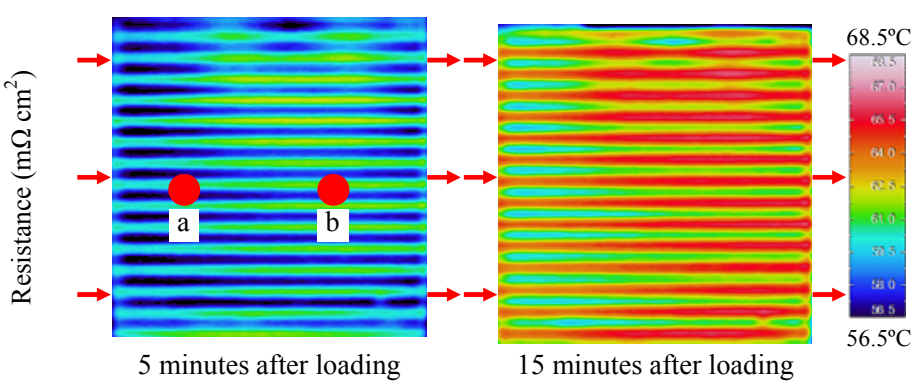

(a) Change of temperature distribution

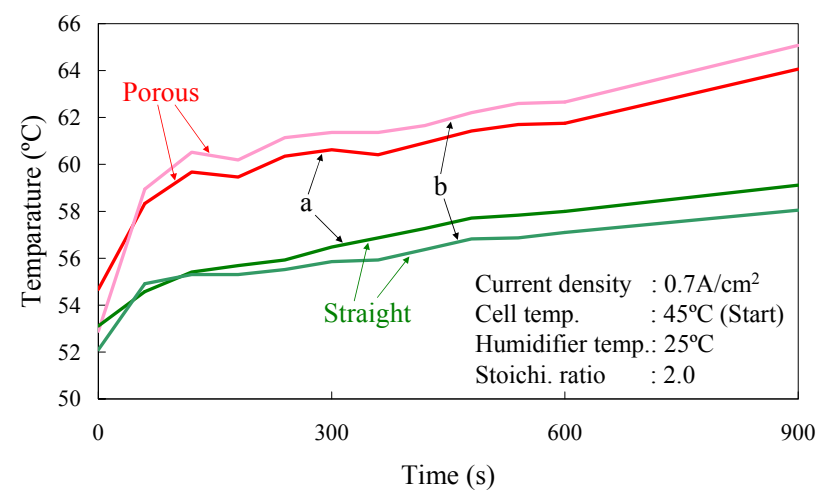

(b) Temperature change at points a and $\mathrm{b}$

Fig. 12 Temperature distribution of the cell with porous flow field and the comparison of temperature at points $\mathrm{a}$ and $\mathrm{b}$ with that of the cell with straight channels 
始時のセル温度は $45^{\circ} \mathrm{C}$, カソード側空気とアノード側純水素をともに $\lambda=2.0$ とし, 電流密度はそれぞれ $0.4 \mathrm{~A} / \mathrm{cm}^{2}$, $0.7 \mathrm{~A} / \mathrm{cm}^{2}$ である，相対湿度が高い場合（図 11(a)），比較的フラッディングが生じにくいサーペンタイン流路型に おいても運転ができなくなっているのに対し，多孔体型は定常運転を継続できることが確認される，一方，相対 湿度が低い場合には (図 11(b))，ストレート流路型が安定運転可能であるのに対し，多孔体型は時間とともにセ ル抵抗の増大とともにセル電圧が下降し続け, 約 1100 秒で運転不能となっている. これは, 多孔体型セパレータ を有する電池がドライアウトしやすい特性を持つことを示している.

多孔体型セパレータを用いた電池のドライアウト特性の詳細を調べるために, 電池内の温度分布測定を行った. 図 12(a)は，図 11(b)の運転時における多孔体型電池の運転開始 5 分後ならびに 15 分後（シャットダウン 3 分前） の温度分布である.アノード側にはストレート流路型のセパレータを用いているため温度分布は縞模様に見えて おり，温度の高い部分が GDL 表面，低い部分がセパレータのリブ表面である．セル B では冷却水を用いていな いため, 運転開始後に徐々に温度が上昇していき，15 分後には下流部（図 12(a)では右側）の温度のほうが高く なっていることが確認される，これは，図 6 で示したように，上流部ではドライアウトが生じ電流密度が低下す る一方, 水蒸気濃度の高い下流部で電流密度が高くなり, この発電分布に対応した熱発生により図 12(a)の温度分 布が形成されたものと推察される. 図 12(b)は，図 12(a)に示したガス流入部付近（a 点）と排出口付近（b 点）の 温度の時間変化を多孔体型とストレート流路型セパレータを用いた場合それぞれに対して示したものである．発 電開始直後に多孔体型を用いた場合の方が $5^{\circ} \mathrm{C}$ ぼ゙温度が高くなることが確認できる．これは，空隙率が $97 \%$ と 非常に高い多孔体型セパレータの熱伝導率が低いこと，および接触電気抵抗と同様に多孔体と他の部材との接触 熱抵抗が大きいことに起因するものと考えられる. また, 多孔体型では排出口付近 (b 点側)，ストレート流路型 では流入口付近（a 点側）の方が高い温度となっている. 多孔体型では流入口付近でドライアウトにより発電状 況が低下, 熱発生が少なくなるのに対し，ストレート流路型ではドライアウトの影響は小さいため, 酸素濃度が 高い流入口付近で発電状況がより良好となり, 熱発生も多くなっていると説明できる. なお, ストレート流路型 においても運転が 50 分を超えると $\mathrm{a}$ 点と $\mathrm{b}$ 点の温度関係が $62^{\circ} \mathrm{C}$ を境に逆転し，排出口付近の方が温度は高くな った．このことから，セル性能に与える影響は，セル温度がある一定值を超え供給ガスの相対湿度が低下すると 酸素濃度から膜の湿潤状態が支配的になっていくものと推察される. なお， ストレート流路型において湿潤状態 が支配的に転じる温度 $62^{\circ} \mathrm{C}$ が, 図 $12\left(\right.$ b) で見られる多孔体型の約 $57^{\circ} \mathrm{C}$ りも高い理由として, 流路型におけるリ ブ構造が凝縮水の保水効果に寄与している可能性が挙げられる. 以上より, 多孔体型セパレータを用いた電池が ドライアウトを起こしやすい特性は, 多孔体型セパレータの低い熱伝導性に起因し, 固体高分子膜の温度が上昇 しやすいことが原因であると言える。この解決のためには，多孔体の空隙率を多少下げることなどにより多孔体 自体の熱伝導率を上昇させるとともに，多孔体と他のセル部材との接触熱抵抗を減少させる必要がある.

今回用いた多孔体は $\mathrm{Ni}$ 製，平均空隙率約 $97 \%$ ，厚さは $1.4 \mathrm{~mm}$ であり，優れた耐フラッディング性能とドライ アウトを起こしやすい特性が確認された. 3 ・2 節で検討した耐フラッディング性向上の機構から, 多孔体繊維の 親水性の特性が担保されていれば空隙率や厚さが而フラッディング性能に及ぼす影響は小さいと予想され，空隙 率を多少下げたり多孔体厚さを薄くすることは良好な耐フラッディング性能を維持したまま耐ドライアウト性能 を向上させる有効な方策であると推察される.また, 多孔体厚さを薄く寸ることは電池の小型化にも有効である. 一方，これらの方策はカソードガスの圧力損失増大や耐プラッギング性能の悪化を引き起こすことが懸念される ため, 用途に応じて多孔体を設計することも重要である.

\section{4. 結言}

多孔型流路を有する固体高分子形燃料電池の性能特性を明らかにするとともに, 電池内部の凝縮水挙動の観察 および温度分布測定を行うことにより，基本特性に対応する電池内部現象の検討を行った．得られた主な結果は 以下の通りである.

(1) 多孔型流路を有する電池は耐フラッディング性に優れ, 低空気流量および高電流密度運転に有利である. また，低い圧力損失でサーペンタイン流路型と同等の凝縮水排出および電圧変動の小さな運転が可能である. 一 方，ドライアウトを生じや寸い特性があるとともに，多孔体と他のセル部材との接触電気抵抗を小さくし，抵抗 過電圧の影響を減少させることも課題である. 
（2）多孔体型セパレータは，GDL 表面に排出された凝縮水をすぐに多孔体繊維により引き上げることが可能 であり，GDL 表面からの優れた凝縮水排出性を有する。これより，GDL 内部へ効率よく酸素を供給可能となり， 凝縮水の影響を受けやすい低流量および高電流密度運転において優れた発電性能, および電圧変動の少ない安定 運転が実現可能になるものと考えられる.また,こうした多孔体型電池の優れた耐フラッディング特性において, 親水性である多孔体の特性が重要である.

（3）多孔型流路を用いた電池がドライアウトを起こしやすい特性は，多孔体型セパレータの低い熱伝導性に 起因し，固体高分子膜の温度が上昇しやすいことが原因であると考えられる．このため，多孔体の空隙率を多少 下げることなどにより多孔体自体の熱伝導率を上昇させるとともに，多孔体と他のセル部材との接触熱抵抗を減 少させることが必要である.

\section{謝辞}

本研究の一部は, 株式会社日立製作所との共同研究として実施された.ここに記し, 関係者各位に謝意を 表する.

\section{文献}

(1) Wang, C.-Y., "Fundamental Models for Fuel Cell Engineering”, Chemical Reviews, Vol. 104, No. 10 (2004), pp. $4727-4766$.

(2) Yamada, H., Hatanaka, T., Murata, H., and Morimoto, Y., "Measurement of Flooding in Gas Diffusion Layers of Polymer Electrolyte Fuel Cells with Conventional Flow Field”, Journal of The Electrochemical Society, Vol. 153, No. 9 (2006), pp. A1748-A1754.

(3) Hogarth, W.H.J., Steiner, J., Benziger, J.B., and Hakenjos, A., "Spatially-resolved current and impedance analysis of a stirred tank reactor and serpentine fuel cell flow-field at low relative humidiry", Journal of Power Sources, Vol. 164 (2007), pp. 464-471.

(4) Noponen, M., Ihonen, J., Lundblad, A., and Lindbergh, G., "Current distribution measurement in a PEFC with net flow geometry", Journal of Applied Electrochemistry, Vol. 34 (2004), pp. 255-262.

(5) Liu, Z., Mao, Z., Wu, B., Wang, L., and Schmidt, V.M., "Current density distribution in PEFC", Journal of Power Sources, Vol. 141 (2005), pp. 205-210.

(6) Tüber, K., Pócza, D., and Hebling, C., "Visualization of water buildup in the cathode of transparent PEM fuel cell”, Journal of Power Sources, Vol. 124 (2003), pp. 403-414.

(7) Zhang, F.Y., Yang, X.G., and Wang, C.-Y., "Liquid Water Removal from a Polymer Electrolyte Fuel Cell", Journal of The Electrochemical Society, Vol. 153, No. 2 (2006), pp. A225-A232.

(8) Chikahisa, T., Tabe, Y., Kikuta, K., Nohara, N., and Shinohara, H., "Measurement of Water Production Phenomena, Temperature, and current Density Distributions in a Polymer Electrolyte Fuel Cell", Proceedings of the 4th International Conference on Fuel Cell Science, Engineering and Technology, (2006), [1/1 (CD-ROM) 97016], pp. 1-6.

(9) Tabe, Y., Kikuta, K., Chikahisa, T., and Kozakai, M., "Basic evaluation of separator type specific phenomena of polymer electrolyte membrane fuel cell by the measurement of water condensation characteristics and current density distribution", Journal of Power Sources, Vol. 193 (2009), pp. 416-424.

(10) Kumar, A., and Reddy, R.G., "Materials and design development for bipolar/end plates in fuel cells", Journal of Power Sources, Vol. 129 (2004), pp. 62-67.

(11) Tabe, Y., Lee, Y., Chikahisa, T., and Kozakai, M., "Numerical simulation of liquid water and gas flow in a channel and a simplified GDL model of polymer electrolyte membrane fuel cells using the lattice Boltzmann method", Journal of Power Sources, Vol. 193 (2009), pp. 24-31. 